\title{
Photochemistry of Pesticides, 10 [1] Photodegradation of O,0-Diethyl-S(3,4-dihydro-4-oxobenzo[d][1,2,3]triazin- 3-yl-methyl)phosphorodithioate (Azinphos-ethyl)
}

\author{
W. M. Abdou [2], M. M. Sidky, and H. Wamhoff* \\ Institut für Organische Chemie und Biochemie der Universität Bonn, \\ Gerhard-Domagk-Straße 1, D-5300 Bonn 1 \\ Z. Naturforsch. 42 b, 907-910 (1987); received February 26, 1987 \\ Azinphos Ethyl, Photodegradation, 4-Oxobenzo[d][1,2,3]triazines, O-Phosphates, \\ N-Methyl-anthranilic Acid \\ The photodegradation of Azinphos-ethyl (1) in chloroform and methanol solution has been \\ studied. 3,4-Dihydro-3-methyl-4-oxobenzo[d][1,2,3]triazine (3), 3,4-dihydro-4-oxo-benzo[d]- \\ $[1,2,3]$ triazine (5), O,O-diethyl-O(3-methylbenzo[d] [1,2,3]triazine-4-yl)phosphate (8), N-methyl- \\ anthranilic acid (11) (in methanol: methyl ester 12), and sulfur have been isolated and charac- \\ terized as photoproducts. The decay mechanism is discussed.
}

\section{Introduction}

In the course of our investigations on the photochemistry of pesticides, we have recently $[1,3]$ cast our attention on photolysis studies of heterocyclic pesticides carrying phosphate and thiophosphate rests. Organophosphates and -thiophosphates possess high insecticidal activity and are widely applied [4-6]. Photochemical studies on these compounds offer valuable knowledge about the role displayed by the solar UV irradiation on insolation (exposure to sunlight) of these pesticides.

In the present investigation, we have studied the photolysis of O,O-diethyl-S(3,4-dihydro-4-oxobenzo[d][1,2,3]triazin-3-yl-methyl)phosphorodithioate (azinphos-ethyl) (1), marketed under the names Bayer 16259, ENT 22014, Gusathion $\mathrm{A}^{\circledR}$, Ethyl Gusathion ${ }^{\circledR}$ [7]. Azinphos-ethyl (1) and its methyl ester analogue azinphos-methyl have found broad application as insecticides in the widest sense $[4,7]$.

As early as 1959 , the first qualitative investigations have been undertaken to study the influence of light and breakdown of azinphos [8], and later on, the effect of light, temperature, and $\mathrm{pH}$ has been investigated on the degradation of azinphos-methyl [9]. The latter study has been carried out in micro scale on ${ }^{14} \mathrm{C}$-labelled azinphos-methyl in water and on glass surfaces to form $\mathrm{CHCl}_{3}$ - and water soluble breakdown products. Some of the compounds indentified

\footnotetext{
* Reprint requests to Prof. Dr. H. Wamhoff.
}

Verlag der Zeitschrift für Naturforschung, D-7400 Tübingen 0932-0776/87/0700-0907/\$ 01.00/0 have been benzazimide, anthranilic acid, N-methylbenzazimide sulfide, and $\mathrm{N}$-methylbenzazimide. Traces of mercaptomethylbenzazimide and of the oxygen analogue of azinphos-methyl have been also claimed to be found. This easy photodegradation, even in sunlight, of azinphos-methyl, a kind of 3 -alkyl substituted 4-oxo-benzo[d][1,2,3]triazine is surprising, after it is known from several photochemical investigations that 3-alkyl-4-oxobenzo[d]$[1,2,3]$ triazines are in general stable to irradiation with UV light, while the 3-aryl analogues lose nitrogen to form 1-aryl-benzazetinones and subsequent products $[10-12]$.

\section{Results and Discussions}

In our present systematic study, we have irradiated an $1 \%$ chloroform solution of azinphos-ethyl 1 for $200 \mathrm{~h}$ in a Pyrex photoreactor using a high pressure mercury lamp $(\lambda>313 \mathrm{~nm})$. The photolysate was separated by chromatography on silica gel whereby besides elemental sulfur, four crystalline products were isolated, namely: 3,4-dihydro-3methyl-4-oxobenzo[d][1,2,3]triazine (3) (3-methylbenzazimide), 3,4-dihydro-4-oxobenzo[d][1,2,3]triazine (5) (benzazimide), N-methyl anthranilic acid (11), and O,O-diethyl-O(3-methylbenzo[d] $[1,2,3]$ triazol-4-yl)phosphate $(\mathbf{8})$. Thus, with respect to $\mathbf{3}$ and $\mathbf{5}$ we were able to isolate products identical with those of Liang and Lichtenstein [9], but with $\mathbf{8}$ and 11 we have got different breakdown products. 


\section{Scheme 1}

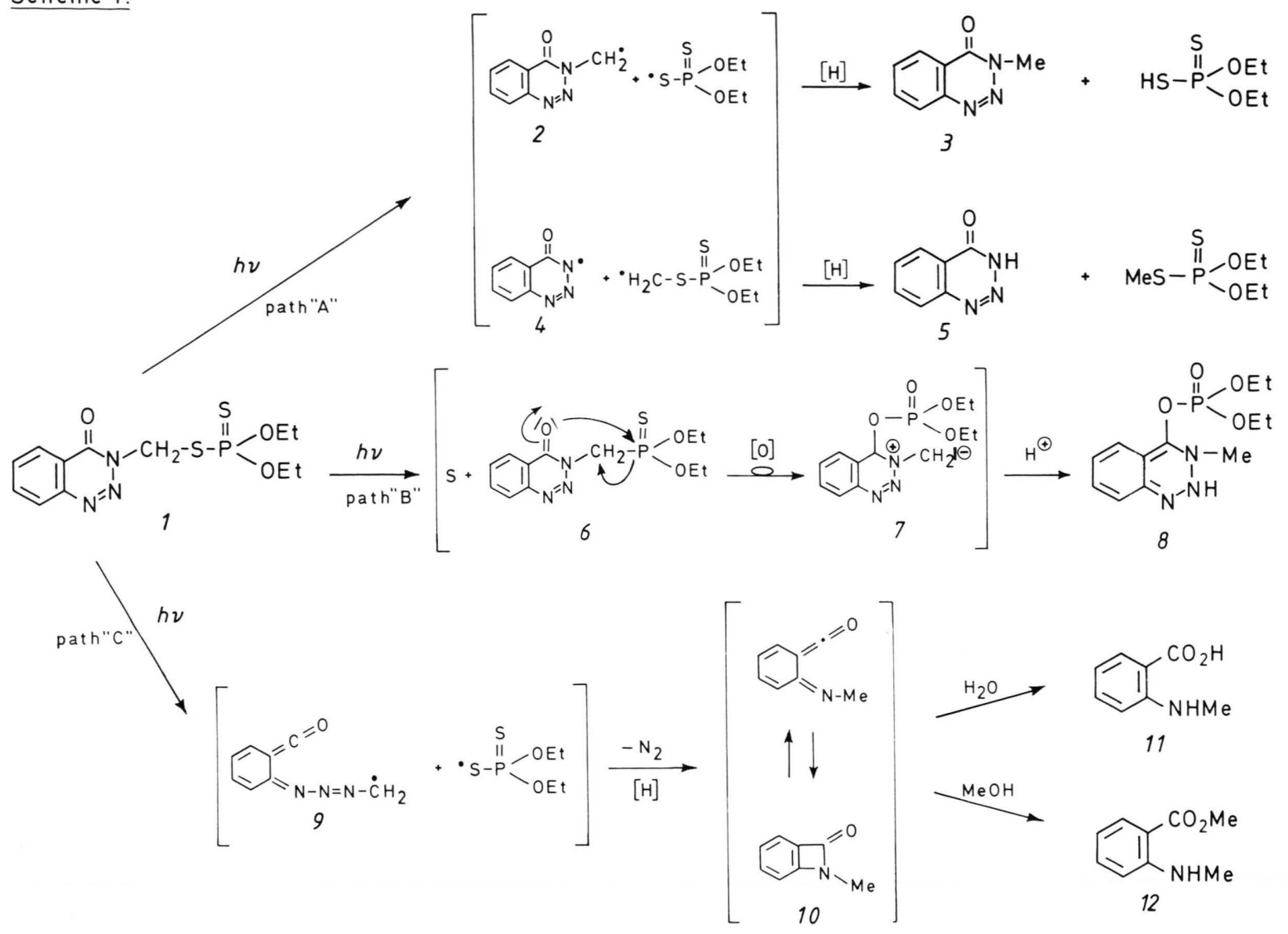

The first three compounds $\mathbf{3}, \mathbf{5}$, and $\mathbf{1 1}$ were characterized by comparison with authentic samples (cf. experimental part). The fourth product, 8 , which is unequivocally different from an "oxygen analogue of azinphos [9]" is assigned to be phosphate $\mathbf{8}$ basing upon the following evidences: (a) Elemental analysis and MS agree with formula $\mathrm{C}_{12} \mathrm{H}_{18} \mathrm{~N}_{3} \mathrm{O}_{4} \mathrm{P}$ (299.2). (b) The IR spectrum does not exhibit any carbonyl band in the $1650-1800 \mathrm{~cm}^{-1}$ region (for comparison, 1: $v_{\mathrm{C}=\mathrm{O}}=1690 \mathrm{~cm}^{-1}$ ); however, characteristic absorption bands are observed at $3450(\mathrm{NH})$ and 1625 (ring vibration), as well as at $1280(-\mathrm{P}=\mathrm{O}$, free $)$ and at $1030 \mathrm{~cm}^{-1}\left(\frac{\mathrm{P}}{\mathrm{C}}-\mathrm{O}-\mathrm{C}_{2} \mathrm{H}_{5}\right)$ [13]. (c) The ${ }^{1} \mathrm{H}$ NMR spectrum of 8 discloses signals at $\delta=1.42(\mathrm{t}, \mathrm{P}(\mathrm{O})$ $\left.\mathrm{O}-\mathrm{CH}_{2}-\underline{\mathrm{CH}_{3}}\right), 4.28\left(\mathrm{q}, \mathrm{P}(\mathrm{O}) \mathrm{O}-\underline{\mathrm{CH}_{2}}-\mathrm{CH}_{3}\right)$, each with $J=8.5 \mathrm{~Hz}$, while a methyl group appears as singlet at $3.06 \mathrm{ppm}$. Moreover, a NH proton is found at $\delta=13.35 \mathrm{ppm}$ (exchangeable with $\mathrm{D}_{2} \mathrm{O}$ ). (d) The ${ }^{31} \mathrm{P}$ NMR spectrum shows a resonance signal at $\delta=$
$-4.91 \mathrm{ppm}$, which lends as additional support to the assigned phosphate constitution and rules out alternative phosphonate constitutions [14].

Upon changing the solvent from chloroform to methanol (with improving the yield) the photodegradation of 1 results in the formation of elemental sulfur, 3, 5, 8, and methyl $\mathrm{N}$-methylanthranilate $\mathbf{1 2}$.

The formation of the benzo[d] [1,2,3]triazinones $\mathbf{3}$ and $\mathbf{5}$ during the photoreaction of $\mathbf{1}$ in chloroform or methanol can be rationalized by a pathway "A" ( $c f$. Scheme 1) involving homolytic cleavage of the side chain, either of the $\mathrm{N}-\mathrm{CH}_{2}-$ or of the $-\mathrm{CH}_{2}-\mathrm{S}$ bond; the triazinone radicals formed by this way, $\mathbf{2}$ and/or $\mathbf{4}$ furnish products $\mathbf{3}$ and $\mathbf{5}$ via hydrogen abstraction; $\mathbf{3}$ and $\mathbf{5}$ can be considered to be stable against further UV irradiation according to literature reports $[10,11]$.

The formation of the phosphate $\mathbf{8}$ can be explained by path "B" in terms of initial desulfuration leading 
to intermediate 6. Photochemical extrusion of sulfur from 1 meets a well documented analogy in the photolysis of various organic sulfides (and sulfoxides) leading, e.g. to the corresponding alkanes [15]; similarly, 2-methylmercapto-1,3,5-triazine herbicides ("triatynes") are known to be cleaved homolytically at the $\mathrm{C}-\mathrm{S}$ bond [16]. Intramolecular rearrangement of $\mathbf{6}$ followed by or concurrent with its oxidation, then gives product 8 . Photooxidations of the type $>\mathrm{P}=\mathrm{S} \rightarrow>\mathrm{P}=\mathrm{O}$ are well documented for thiophosphates during insolation [4] or photoreactions $[1,5]$. An alternative pathway for the production of $\mathbf{8}$ involving initial formation of $\mathbf{3}$ and $\mathbf{5}$ along with subsequent attack of trimethyl phosphorodithioate to the 4-carbonyl group seems to be unlikely for several reasons.

Photogeneration of $\mathbf{1 1}$ or $\mathbf{1 2}$ (dependent of the solvent used) can be reasonably interpreted by path " $\mathrm{C}$ " which is in accordance with the mechanisms previously reported by Ege, and by Burgess and Milne [10-12].

\section{Experimental}

Melting points: uncorrected. - Elemental analyses: Mikroanalytisches Laboratorium Dr. F. Pascher, Bonn. - IR spectra: Perkin-Elmer 157-G. - ${ }^{1}$ H NMR spectra: Bruker WH-90 ( $\delta$-values, TMS as internal standard). - ${ }^{31} \mathrm{P}$ NMR: Varian CFT-20 (vs. $85 \% \mathrm{H}_{3} \mathrm{PO}_{4}$ ). - MS: MS-50 of Kratos (A.E.I.). - T.L.C. system: toluene-ethylacetate-ethanol $(6: 3: 1 . \mathrm{v} / \mathrm{v} / \mathrm{v})$. The photolyses were carried out in a Pyrex photoreactor equipped with a mercury high pressure lamp (Philips HPK 125).

Azinphos ethyl (1) was supplied by the Bayer AG, D-5090 Leverkusen.

\section{Photolysis of azinphos ethyl (1)}

\section{a) Irradiation in chloroform}

A solution of azinphos ethyl $(\mathbf{1}, 3.4 \mathrm{~g}, 10 \mathrm{mmol})$ in chloroform $(350 \mathrm{ml})$ was irradiated for $200 \mathrm{~h}$. Then, the reaction mixture was evaporated in vacuo. The residue obtained (yellow oil) was chromatographed on silica gel; system: toluene, then with toluene containing increasing amounts of ethyl acetate.

Fraction (100\% toluene) gave $780 \mathrm{mg}(23 \%)$ of unchanged 1, m.p. $52-54^{\circ} \mathrm{C}$ (petroleum ether 60-80; lit. m.p. $52-54{ }^{\circ} \mathrm{C}$ [17]); MS: $m / z 346\left(\mathrm{M}^{+}\right)$.

Fraction $(9: 1,500 \mathrm{ml})$ gave $272 \mathrm{mg}(17 \%)$ of a yellow product; recrystallization from cyclohexane furnished yellow leaflets of m.p. $122{ }^{\circ} \mathrm{C}$, and identified as 3,4-dihydro-3-methyl-4-oxo-benzo[d]$[1,2,3]$ triazine (3) (lit. m.p. $123-124{ }^{\circ} \mathrm{C}[18]$ ); MS: $\mathrm{m} / \mathrm{z} 161\left(\mathrm{M}^{+}\right)$.

Fraction $(9: 1$, further $800 \mathrm{ml})$ provided another yellow crytsalline material: $255 \mathrm{mg}(8 \%)$; recrystallized from acetone to give pale yellow crystals of m.p. $162{ }^{\circ} \mathrm{C}$, and identified as the phosphate 8 .

Analysis for $\mathrm{C}_{12} \mathrm{H}_{18} \mathrm{~N}_{3} \mathrm{O}_{4} \mathrm{P}$ (299.2)

$\begin{array}{lllllr}\text { Calcd } & \text { C } 48.81 & \text { H } 5.76 & \text { N } 13.82 & \text { P } & 9.99 \text {, } \\ \text { Found } & \text { C } 48.16 & \text { H } 6.06 & \text { N } 14.04 & \text { P } 10.35 .\end{array}$

MS: $m / z 299\left(\mathbf{M}^{+}\right)$.

IR (KBr): $3450(\mathrm{NH}), 1625,1600,1570(\mathrm{C}=\mathrm{C}$, $\mathrm{C}=\mathrm{N}$ ring vibrations $), 1280(\mathrm{P}=\mathrm{O}$, free $), 1030 \mathrm{~cm}^{-1}$ $\left(-\mathrm{P}-\mathrm{O}-\mathrm{C}_{2} \mathrm{H}_{5}\right)$.

${ }^{1} \mathrm{H}$ NMR (DMSO-d $\left.{ }_{6}\right): \delta 1.42\left(\mathrm{dt}, \mathrm{POCH}_{2} \mathrm{CH}_{3}, J=\right.$ $8.5 \mathrm{~Hz}, J=0.8 \mathrm{~Hz}), 3.06\left(\mathrm{~s}, \mathrm{~N}-\mathrm{CH}_{3}\right), \overline{4.28}(\mathrm{dq}$, $\left.\mathrm{POCH}_{2} \mathrm{CH}_{3}, J=8.5 \mathrm{~Hz}, J=10.2 \mathrm{~Hz}\right), 7.15-7.78$ $\left(\mathrm{m}, \mathrm{H}_{\mathrm{ar} .}\right), 13.35\left(\mathrm{~s}, \mathrm{NH}\right.$, exchangeable with $\left.\mathrm{D}_{2} \mathrm{O}\right)$.

${ }^{31} \mathrm{P}$ NMR (DMSO- $\mathrm{d}_{6} / \mathrm{CDCl}_{3}$ ): $\delta-4.91 \mathrm{ppm}$.

Fraction $(8: 2,500 \mathrm{ml})$ contained $120 \mathrm{mg}(37.5 \%)$ of yellow crystals of m.p. $119-122{ }^{\circ} \mathrm{C}$, identified as sulfur (T.L.C., MS).

Fraction (up to $6: 4)$ gave $398 \mathrm{mg}(28 \%)$ of a yellow material, recrystallized from ethanol/ether $(4: 1$, $\mathrm{v} / \mathrm{v}$ ) of m.p. $210-212{ }^{\circ} \mathrm{C}$, shown to be 3,4 -dihydrobenzol[d][1,2,3]triazine-4-one (5), mixed m.p. with authentic probe (lit. m.p. $210{ }^{\circ} \mathrm{C}$ [19]); MS: $\mathrm{m} / \mathrm{z}$ $147\left(\mathrm{M}^{+}\right)$.

Fraction $(5: 5,11)$ afforded a colorless crystalline product $74 \mathrm{mg}(5 \%)$ which proved to be N-methyl anthranilic acid (11) of m.p. $170{ }^{\circ} \mathrm{C}$; lit. m.p. $168-170{ }^{\circ} \mathrm{C}$ [20]. Characterization by comparison with an authentic specimen.

\section{b) Irradiation in methanol}

A solution of azinphos ethyl $(1,3.4 \mathrm{~g}, 10 \mathrm{mmol})$ in methanol $(340 \mathrm{ml})$ was irradiated for $200 \mathrm{~h}$ under the conditions described above a). Working up the photolysate in the usual manner resulted in isolation and identification of methyl N-methylanthranilate $\mathbf{1 2}$ (114 mg, 7\%), unchanged azinphos ethyl 1 (510 mg, 15\%), 3,4-dihydro-3-methyl-4-oxo-benzo[d]$[1,2,3]$ triazine $(3)(352 \mathrm{mg}, 22 \%)$, the phosphate 8 (320 mg, 11\%), sulfur (125 mg, 38\%), and 3,4-dihydro-4-oxobenzo[d][1,2,3]triazine (5) $\quad(472 \mathrm{mg}$, $33 \%$ ), respectively.

\section{c) Irradiation of $\mathbf{3}$ and/or $\mathbf{5}$ in methanol}

3,4-Dihydro-3-methyl-4-oxobenzo[d][1,2,3]triazine (3) $(1 \mathrm{~g}, 6 \mathrm{mmol})$ and/or 3,4-dihydro-4-oxo- 
benzo[d][1,2,3]triazine (5) $(1 \mathrm{~g}, \quad 6 \mathrm{mmol}) \quad$ in methanol $(100 \mathrm{ml})$ were irradiated like under a) for 150 h. T.L.C. analysis did not reveal any trace of products formed, and only starting material was recovered in quantitative yield.

During the working up of the reaction mixture obtained from the photolysis of $\mathbf{1}$ in chloroform or methanol, minor constituents and traces could also be isolated, but an identification failed.

This work was supported by the Fonds der Chemischen Industrie, the ASRT Cairo, and the Bayer AG. - W. M. A. thanks the Heinrich-HertzStiftung for granting a research fellowship.
[1] Part 9 of the Series: W. M. Abdou, M. M. Sidky, and H. Wamhoff, J. Agr. Food Chem. 1987, in press.

[2] Research Fellow of National Research Centre, Cairo, A. R. Egypt.

[3] W. M. Abdou, L. Born, H. Hulpke, M. R. Mahran, M. M. Sidky, and H. Wamhoff, Phosphorus Sulfur 29, 179 (1987).

[4] K. H. Büchel (ed.): Chemistry of Pesticides, WileyInterscience, New York (1983).

[5] G. Schrader (ed.): Die Entwicklung neuer insektizider Phosphorsäureester, Verlag Chemie, Weinheim (1963).

[6] N. N. Melnikov, Chemistry of Pesticides, Springer, New York (1971)

[7] C. A. Anderson, J. C. Cavagnol, C. J. Cohen, A. D. Cohick, R. T. Evans, L. J. Everett, J. Hensel, R. P. Honeycutt, and E. R. Levy, Residue Rev. 51, 123 (1974); C. A. 81, 164,459e (1974); H. Neunhoeffer, in A. R. Katritzky and C. W. Rees (eds): Comprehensive Heterocyclic Chemistry, Vol. 3 (A. J. Boulton and A. McKillop (eds)), Pergamon Press, Oxford (1984), p. 369, 379 ff.; H. Neunhoeffer, in A. Weissberger and E. C. Taylor (eds): The Chemistry of Heterocyclic Compounds, Vol. 33, p. 165, Wiley-Interscience, New York (1978).

[8] J. W. Cook and R. Ottes, J. Assoc. Off. Agric. Chemists 41, 211 (1959); C. A. 53, 9556h (1959).

[9] T. T. Liang and E. P. Lichtenstein, J. Econ. Entomol. 65, 315 (1972); C. A. 77, 15,547x (1972).
[10] G. Ege, Angew. Chem. 77, 723 (1965); Angew. Chem., Int. Ed. Engl. 4, 699 (1965); E. M. Burgess and G. Milne, Tetrahedron Lett. 1966, 93.

[11] G. Ege, Chem. Ber. 101, 3079 (1968); G. Ege and F. Pasedach, ibid. 101, 3089 (1968).

[12] G. Ege, P. Arnold, E. Beisiegel, I. Lehrer, H. Suschitzky, and D. Price, Liebigs Ann. Chem. 1976, 946.

[13] L. J. Bellamy (ed.): The Infrared Spectra of Complex Molecules, Wiley, New York (1964); L. W. Daasch and D. C. Smith, Anal. Chem. 22, 852 (1951).

[14] M. M. Crutchfield, C. H. Dungan, J. H. Letcher, V. Mark, and J. R. van Wazer, ${ }^{31} \mathrm{P}$ Nuclear Magnetic Resonance, p. 227, Interscience, New York (1967).

[15] Cf. J. D. Doyle, Introduction to Organic Photochemistry, p. 159, Wiley, Chichester (1986); H. Dürr, in Houben-Weyl-Müller: Methoden der Organischen Chemie, 4th ed., Vol. 4, part 5b, Thieme, Stuttgart (1975), p. $1014 \mathrm{ff}$. and literature cited therein; V. Boekelheide, I. D. Reingold, and M. Tuttle, J. Chem. Soc., Chem. Commun. 1973, 406; J. Bruhin and W. Jenny, Tetrahedron Lett. 1973, 1215.

[16] B. E. Pape and M. J. Zabik, J. Agr. Food Chem. 18, 202 (1970).

[17] W. Lorenz (Bayer AG), Ger. 927,270 (1953); C. A. 52, 2908 (1958)

[18] E. M. Van Heyningen, J. Am. Chem. Soc. 77, 6562 (1955).

[19] G. Jacini, Gazz. Chim. Ital. 77, 308 (1947).

[20] H. Hünecke, Ber. Dtsch. Chem. Ges. 60, 1455 (1927). 